\title{
Tuberin: A Stimulus-Regulated Tumor Suppressor Protein Controlled by a Diverse Array of Receptor Tyrosine Kinases and G Protein-Coupled Receptors
}

\author{
Eddy H.T. Wu Kelvin K.H. Wu Yung H. Wong \\ Department of Biochemistry, Molecular Neuroscience Center, and Biotechnology Research Institute, \\ Hong Kong University of Science and Technology, Hong Kong, SAR, China
}

\section{Key Words}

$\mathrm{Akt} \cdot \mathrm{G}$ protein $\cdot \mathrm{G}$ protein-coupled receptor $\cdot$ Growth

factor $\cdot$ Receptor tyrosine kinase $\cdot$ Tuberin

\begin{abstract}
Tuberin, a tumor suppressor protein, is involved in various cellular functions including survival, proliferation, and growth. It has emerged as an important effector regulated by receptor tyrosine kinases (RTKs) and G protein-coupled receptors (GPCRs). Regulation of tuberin by RTKs and GPCRs is highly complex and dependent on the type of receptors and their associated signaling molecules. Apart from Akt, the first kinase recognized to phosphorylate and inactivate tuberin upon growth factor stimulation, an increasing number of kinases upstream of tuberin have been identified. Furthermore, recruitment of different scaffolding adaptor components to the activated receptors appears to play an important role in the regulation of tuberin activity. More recently, the differential regulation of tuberin by various $G$ protein family members have also been intensively studied, it appears that $G$ proteins can both facilitate (e.g., $\mathrm{G}_{\mathrm{i} / \mathrm{o}}$ ) as well as inhibit (e.g., $\mathrm{G}_{\mathrm{q}}$ ) tuberin phosphorylation. In the present review, we attempt to summarize our emerging understandings of the roles of RTKs, GPCRs, and their cross-talk on the regulation of tuberin.

Copyright $\odot 2007$ S. Karger AG, Basel
\end{abstract}

\section{Introduction}

Tuberin, encoded by the tuberous sclerosis complex 2 (tsc2) gene, is an important tumor suppressor protein. The $t s c 2$ gene was identified through its association with a familial autosomal multisystem disorder known as tuberous sclerosis complex (TSC) with a prevalence of 1 in $6,000-10,000$ births $[1,2]$. Over the past decade, considerable progress has been made in understanding the molecular genetics of TSC, which is highlighted by the identification of $t s c 1$ and $t s c 2[3,4]$; mutations in either $t s c 1$ or $t s c 2$ cause the disease. In vivo, tuberin and hamartin ( $t s c 1$ product) form heteromers and the hamartin-tuberin interaction appears to be important for the stability of each protein [5]. Human $t s c 2$ gene is located on chromosome 16 (16p13.3) and its $198-\mathrm{kDa}$ product tuberin is ubiquitously expressed [1]. Tuberin can be found at multiple sites within the cell including the cytosol, microsomes, cytoskeletal components and nucleus [6]. Whilst some studies have suggested that Akt activity influences tuberin levels $[7,8]$, other studies were unable to observe an affect $[9,10]$. Consistent with the latter, mitogenic stimulation induces Akt activity, whereas tuberin protein amounts remain constant [11, 12]. The Akt-mediated phosphorylation of tuberin at $\mathrm{Ser}^{939}$ is thought to be crucial for the regulation of tuberin localization. Tuberin is thought to be localized to the mitochondria and also

Dr. Yung H. Wong

Department of Biochemistry

Hong Kong University of Science and Technology, Clear Water Bay

Kowloon, Hong Kong, SAR (China)

Tel. +852 2358 7328, Fax +852 2358 1552, E-Mail boyung@ust.hk 
translocated to the nucleus in the late G1 phase of cell mitosis [13]. Upon activation of Akt and phosphorylation of tuberin, it is thought that tuberin is localized in the cytosol, where it is bound to 14-3-3 and physically sequestered away from hamartin, unable to form a stable heteromer [14]. Tuberin is highly evolutionarily conserved and shows a high degree of similarity between species, ranging from fission yeast Schizosaccharomyces pombe, fruit fly Drosophila, Japanese pufferfish Fugu rubripes, rat, mouse, to human [15-20].

The critical importance of the $t s c 2$ gene for maintaining normal biological functions could be inferred by the manifestations of the disease. Patients with TSC develop hamartomas and benign tumors in the brain, heart and kidney, and they can exhibit cognitive defects, epilepsy and autism [4, 21-24]. These manifestations illustrate the importance of tuberin signaling in the central nervous system. Furthermore, the $t s c 2^{-/-}$null mice are embryonically lethal, demonstrating that tuberin is essential for development [25]. Until recently, it was unclear how tuberin exercised its functions as a tumor suppressor protein. Recent exciting discoveries have suggested a role for tuberin in modulating the activity of TOR (target of rapamycin), a central regulator of cell growth and proliferation [26-28].

Apart from demonstrating the role of tuberin in the regulation of cell growth and proliferation, results from several laboratories over the past few years have provided new insights into how tuberin might affect cell survival, cell adhesion, cell morphology, cell migration, neuronal differentiation, regulation of cellular energy, post-Golgi transport, or protein trafficking in the cell [29-35]. A particularly interesting feature of tuberin is the presence of multiple serine, threonine and tyrosine phosphorylation sites [36,37], suggesting that the functional activity of tuberin could be potentially regulated by different signaling molecules. Furthermore, a previous study has demonstrated that tuberin is a component of lipid rafts [35]. Lipid rafts are enriched in molecules such as $G$ protein-coupled receptors (GPCRs), G proteins, receptor tyrosine kinases (RTKs), Src family tyrosine kinases, protein kinase $\mathrm{C}$, and nitric oxide synthase [38]. This further supports a scenario wherein tuberin is able to interact with various signaling molecules and affect their functions. Akt-dependent phosphorylation of tuberin has been identified as an important step which regulates mammalian TOR (mTOR) and p70 S6 kinase activities in response to activation of RTK by insulin [26, 37]. Apart from insulin, other RTK agonists have the ability to regulate tuberin activity. Is has also become increasingly ap- parent that, like RTKs, GPCRs and G proteins are involved in the regulation of cell growth and survival [39, 40]. Many of these effects may be mediated by tuberin. Although much has been written regarding the molecular genetics of TSC, which is associated with the mutation in or loss of $t s c 2$ gene, few reviews have addressed the mechanisms by which the function of tuberin can be regulated. The current review outlines our emerging understanding of extracellular stimuli-promoted tuberin regulation and the coordination of various stimulus-mediated effects by tuberin.

\section{Regulation of Tuberin by RTKs}

Growth factors regulate the tuberin activity by an elaborate mechanism initiated by RTK dimerization, autophosphorylation, and the sequential recruitment of the adaptor proteins, such as Grb2-associated binder 2 (Gab2) and Casitas B-lineage lymphoma $(\mathrm{Cbl})$, that serve as the adaptors for phosphatidylinositol 3-kinase (PI3K). Recruited PI3K would in turn stimulate Akt phosphorylation and activation [41,42]. Eventually, tuberin would be phosphorylated by activated Akt, disassociated from its binding partners and degraded via a proteasomal mechanism $[29,43]$. The mechanisms by which Akt-mediated phosphorylation of tuberin that lead to the degradation and functional inactivation of tuberin remain unclear. Nevertheless, phosphorylation and inactivation of tuberin is required for activation of mTOR and p70 S6 kinase as well as inhibition of eukaryotic initiation factor $4 \mathrm{E}$ binding protein 1 (4E-BP1, an inhibitor of translation) [9, $44,45]$. Although Akt was the first kinase known to phosphorylate and inactivate tuberin upon insulin or growth factor stimulation $[9,37,45]$, other kinases have also been found to regulate the activity of tuberin (fig. 1). These kinases include MAPK-activated protein kinase 2 (MK2) [46], p90 ribosomal S6 kinase 1 (p90 RSK1) [47], AMP kinase (AMPK) [48] and extracellular signal-regulated kinase (ERK) [49].

The phosphorylation of tuberin by Akt and MK2 promotes the binding of tuberin with 14-3-3 proteins. 14-3-3 proteins are members of a group of proteins that specifically interact with phosphorylated proteins, facilitating the phosphorylation-dependent control of protein activity [50]. Detection of a ternary complex of tuberin, hamartin and 14-3-3 suggests that the tuberin-14-3-3 interaction is compatible with tuberin-hamartin binding and that 14-3-3 proteins interact with the tuberin-hamartin complex [51, 52]. A possible function of the interaction 
Fig. 1. Tuberin, encoded by TSC2. Tuberin is phosphorylated by: Akt at $\operatorname{Ser}^{939}$ and Thr ${ }^{1462}$, ERK2 at Ser ${ }^{664}, \mathrm{MK} 2$ at $\mathrm{Ser}^{1210}$, RSK1 at Ser ${ }^{1798}$ and AMPK at $\mathrm{Thr}^{1227}$ and $\mathrm{Ser}^{1345}$. The hamartin interacting domain spans amino acids 1-418 [134] and the GAP domain spans amino acids 1517-1674 [135].

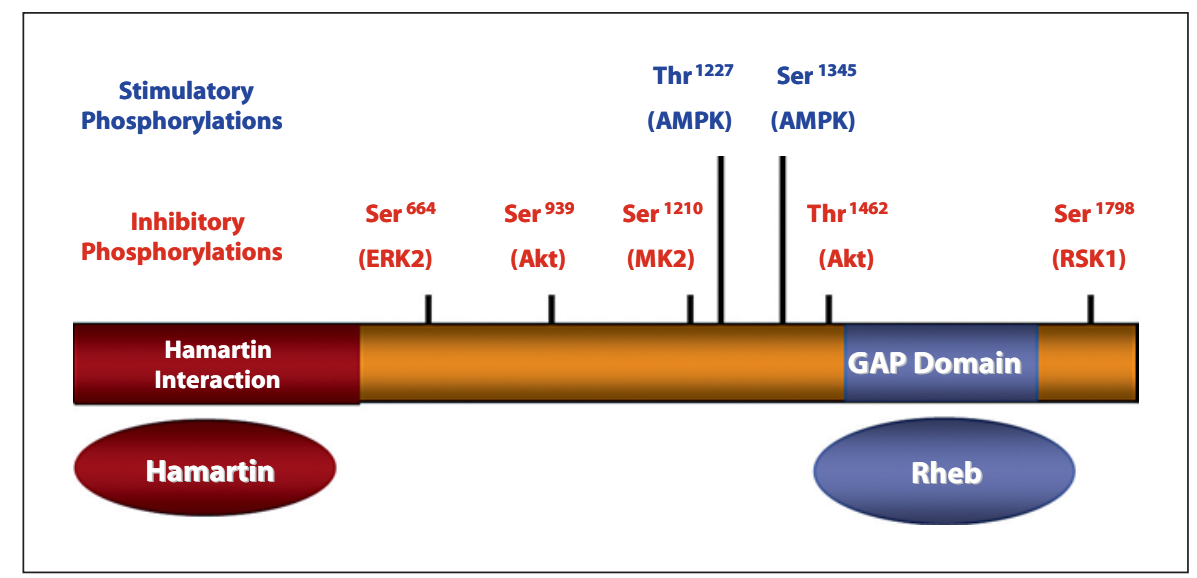

between 14-3-3 proteins and phosphorylated tuberin is to inhibit the formation of tuberin-hamartin complex, in order to decrease the stability of tuberin and release of the activated mTOR [51]. Apart from MK2, ERKs and p90 RSK1 were also found to be able to hinder the tuberinhamartin complex formation and attenuate tuberin activity by inducing tuberin phosphorylation $[47,49]$. Other than to hinder the tuberin-hamartin complex formation, phosphorylation of tuberin at $\operatorname{Ser}^{1798}$ by p90 RSK1 is important for PMA-induced stimulation of p70S6K. This effect is additive to the phosphorylation by Akt at $\mathrm{Ser}^{939}$ and $\mathrm{Thr}^{1462}$ [48]. It is interesting to note that tuberin has been reported as an upstream regulator of the ERK pathway. Loss of tuberin correlates with high ERK activity [53] and significant phosphorylation of ERKs [54]. Restoration of tuberin in $t s c 2^{-/-}$cells remarkably decreased B-Raf activity [55], further demonstrating the negative role of tuberin in the activation of ERKs. The association of tuberin activity to B-Raf and ERK is unclear. Nonetheless, it has been proposed that the Rap1 GTPase activating protein (GAP) activity of tuberin may be involved [55]. Moreover, it should be noted that, as mentioned before, ERKs are able to decrease tuberin activity. Taken together, these observations suggest a positive feedback loop from decreasing activity of tuberin to activation of ERKs. All these phosphorylation events inactivate tuberin and positively regulate the mTOR signaling pathway. In contrast, tuberin was shown to be activated by AMPK phosphorylation at $\mathrm{Thr}^{1227}$ and Ser ${ }^{1345}$ under energy-deprived circumstances [31]. Activated tuberin controls the cell size, thus protecting the cells from apoptosis under energy deprivation. An increasing number of kinases (Akt, ERKs, p90 RSK1, AMPK, MK2) directly upstream of tuberin have been identified, and almost all of them are negative regulators of tuberin. Under a normal physiological system, these kinases may be working in a cooperative manner to produce an additive effect on tuberin regulation.

The first agonist of RTK identified to induce tuberin regulation is insulin $[56,57]$. The mechanism by which insulin and its family members, including insulin-like growth factor (IGF)-I and IGF-II, induces tuberin regulation has been extensively studied. For the insulin family members, insulin receptor substrate (IRS) proteins play a critical role in regulating tuberin. After binding of the insulin and IGF to their receptors, IRS proteins are phosphorylated by RTKs which then act as the binding sites for the recruitment of PI3K. Furthermore, a negative feedback loop from p70 S6 kinase to IRS proteins is responsible for the attenuation of Akt activity in tuberinnull cells $[58,59]$. A similar negative feedback loop involving p70 S6 kinase repression of Akt activation has also been described in Drosophila [60]. This negative feedback program balances the activities between Akt and p70 S6 kinase in order to prevent the cell from inappropriate activation of the mTOR/p70 S6 kinase pathway. A recent study has provided experimental evidence to show that tuberin plays an inhibitory role in this negative feedback loop [61]. In order to maintain insulin signaling to PI3K, tuberin-hamartin complex indirectly induces IRS-1 gene expression and promotes phosphorylation of IRS-1 by restraining the activity of p70 S6 kinase. Both of these two mechanisms, regulation of IRS-1 expression and phosphorylation, act in the same manner toward insulin-PI3K activation (fig. 2). This is consistent with the observations in $t s c 2^{-/-}$cells where p70 S6 kinase is hyperactive and PI3K is defective $[59,62,63]$ and inactivation of tuberin-hamartin complex leads to constitutive p70 S6 


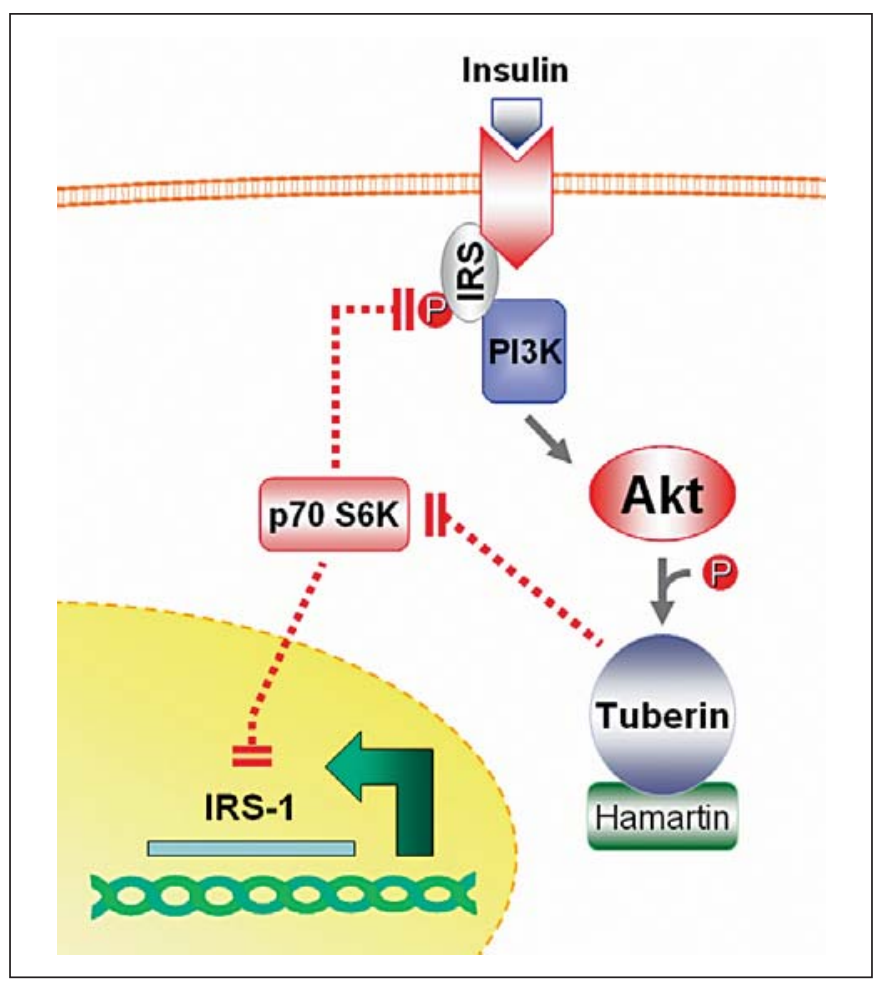

Fig. 2. A negative feedback loop from p70 S6 kinase to IRS proteins. Phosphorylation and expression of IRS proteins, which act as the binding sites for the recruitment of PI3K to stimulated RTK, are inhibited by active p70 S6 kinase. IRS = Insulin receptor substrate; $\mathrm{PI} 3 \mathrm{~K}=$ phosphatidylinositol 3-kinase; p70 S6K = p70 S6 kinase. kinase activity $[64,65]$. In other words, by suppressing the negative feedback loop from p70 S6 kinase to IRS proteins, tuberin is a key positive regulator of PI3K signaling.

Although IRS proteins are the scaffolding proteins for the receptors of insulin family, recruitment of IRS by other RTKs has also been demonstrated. For instance, nerve growth factor (NGF)-activated TrkA receptor is able to recruit IRS proteins in order to stimulate PI3K activity [66]. Therefore, it is likely that NGF is able to affect the activity and phosphorylation level of tuberin. Consistent with this expectation, NGF has indeed been shown to stimulate tuberin phosphorylation through the PI3K/Akt pathway [29] (fig. 3). Besides the participation of PI3K/ Akt pathway, it is interesting to note that free G $\beta \gamma$ complexes released from $\mathrm{G}_{\mathrm{i} / \mathrm{o}}$ proteins are apparently involved in NGF-induced tuberin phosphorylation. G $\beta \gamma$ stimulates tuberin phosphorylation via the PI3K/Akt pathway. It has also been demonstrated that NGF can utilize $G_{i / o}$ proteins to regulate ERKs [67]. The mechanism by which TrkA receptors induce $G \beta \gamma$ release remains unknown. There are scattered reports on growth factor receptors, such as insulin RTK, interacting with G proteins [68-71]. Furthermore, IGF-I has been shown to activate $G_{i}$ to release G $\beta \gamma$ subunits [72]. These findings further reveal and strengthen the important connection between $G_{i / o}$ protein signaling and NGF-induced tuberin regulation.
Fig. 3. A paradigm of regulation of tuberin by various extracellular stimuli. Insulin, EGF, NGF, and agonists of G protein-coupled receptors (CCh, FSH, S1P, and LPA) stimulate phosphorylation of tuberin via Akt/PI3K pathway. ERK, AMPK, MK2, and p90 RSK1 are other identified direct tuberin upstream kinases. Agonists of $\mathrm{G}_{12 / 13}$-coupled receptors inhibit tuberin phosphorylation through RhoA pathway. $\mathrm{G}_{\mathrm{q}}$-coupled receptors can stimulate tuberin phosphorylation via $\mathrm{Ca}^{2+}$ pathway or activate protein tyrosine phosphatases which then dephosphorylate the Akt and result in the inhibition of tuberin phosphorylation. Phosphorylation and inactivation of tuberin is required for activation of mTOR and p70 S6 kinase as well as inhibition of eukaryotic initiation factor $4 \mathrm{E}$ BP1.

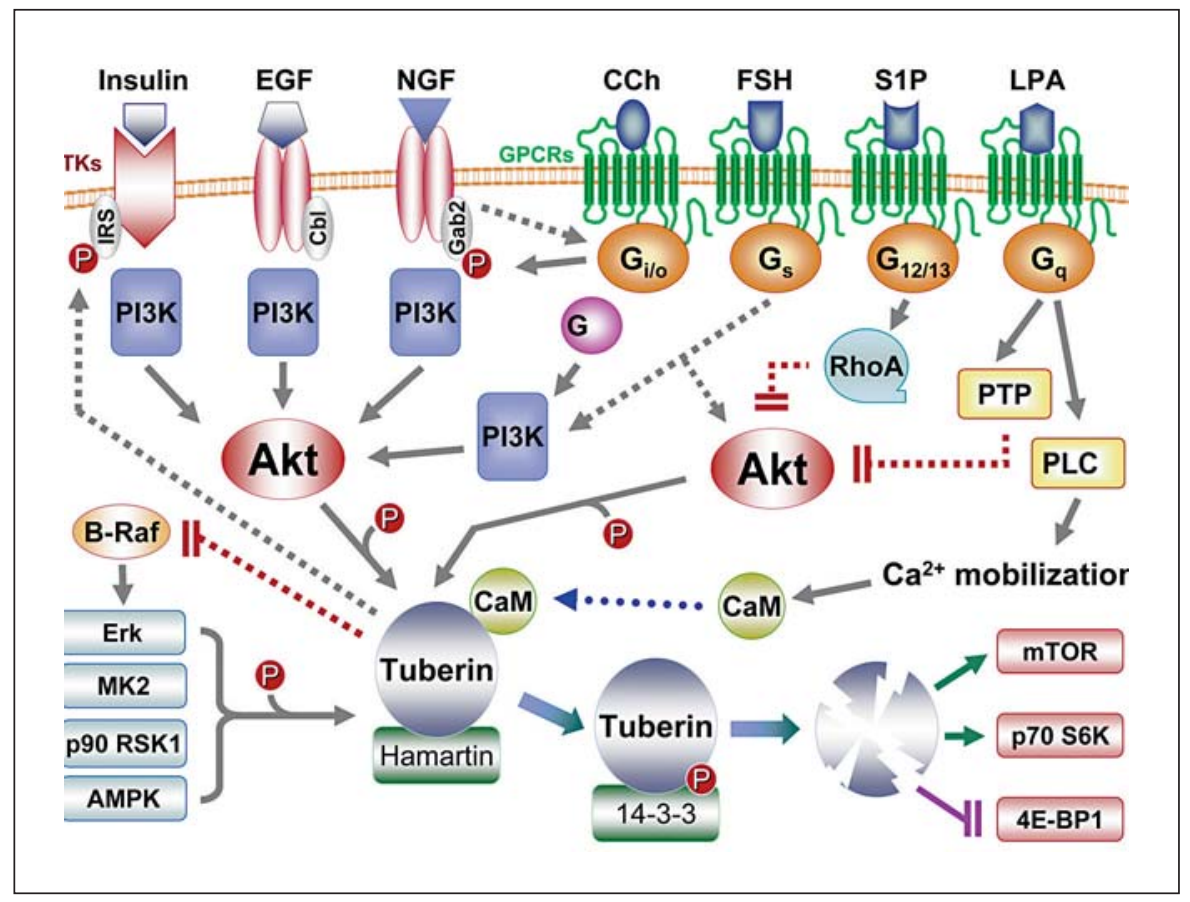


However, not all trophic factor receptors are able to use $\mathrm{G}_{\mathrm{i} / \mathrm{o}}$ proteins to regulate downstream signals. Studies have illustrated that $G_{i / o}$ proteins are not involved in epidermal growth factor (EGF)-induced phosphorylations of tuberin and ERKs $[67,73]$ (fig. 3).

Recruitment of different scaffolding adaptor components to the activated TrkA and the EGF receptor complex may provide an explanation for the involvement of $\mathrm{G}_{\mathrm{i} / \mathrm{o}}$ signaling in NGF-regulated, but not in EGF-induced, tuberin phosphorylation. EGF rapidly induces marked dephosphorylation of $\mathrm{Crk} \mathrm{SH} 3$ domain-binding guanine nucleotide-releasing factor (C3G) and the C3G/CrkL/ Shp2 complex is recruited to the EGF receptor via the adaptor $\mathrm{Cbl}[74,75]$. In contrast to EGF treatment, C3G is persistently tyrosine phosphorylated after NGF treatment. NGF induces the binding of C3G/CrkL/Shp2 to Gab2 and TrkA [75]. In other words, TrkA is able to recruit Gab2 to form a complex, whereas the EGF receptor binds with another adaptor protein Cbl. It is interesting that although both $\mathrm{Cbl}$ and Gab2 serve as PI3K adaptors, only Gab2 can be phosphorylated and regulated by the $\mathrm{G}_{\mathrm{i}}$-coupled $\mathrm{N}$-formyl-methionyl-leucyl-phenylalanine receptor [76]. Thus, it seems that Gab2 may serve as a bridge to link TrkA, $\mathrm{G}_{\mathrm{i} / \mathrm{o}}$ proteins, and PI3K. Although not all RTKs can induce $G_{i / o}$ protein to release $G \beta \gamma$, as we learned from the example of EGF, G proteins and their coupled receptors may play an important role in the regulation of tuberin. While NGF can either directly or indirectly affect the activity of G proteins, GPCRs are primarily responsible for $G$ protein activation. In the next section, we will review how $G$ proteins and their receptors regulate tuberin activity.

\section{Mechanisms of Tuberin Regulation by GPCRs}

GPCRs constitute a large family of single polypeptide chain receptors, with seven transmembrane $\alpha$-helices composed predominantly of hydrophobic residues looping between the extracellular and intracellular regions. A diverse array of external stimuli, including neurotransmitters, hormones, phospholipids, photons, odorants, taste ligands and mitogens, bind to specific GPCRs, which subsequently interact with respective $G$ proteins to induce downstream signaling [77]. Many isoforms of the different $G$ protein subunits have been cloned and classified according to the subtype of their $G \alpha$ subunit into four groups: $G_{s}, G_{i}, G_{q / 11}$ and $G_{12 / 13}$. Under basal conditions, $G$ proteins exist as heterotrimers with GDP bound to the $\mathrm{G} \alpha$. Agonist-stimulated receptor promotes the re- lease of GDP, the binding of GTP, and the dissociation of

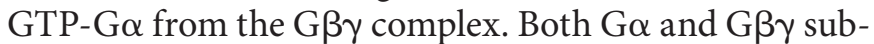
units can regulate downstream effectors in a selective manner that can be independent, synergistic, or antagonistic. Endogenous GTPase activity of the $\mathrm{G} \alpha$ subunit terminates its ability to regulate effector activity and leads to GDP-G $\alpha$ reassociation with G $\beta \gamma$ [77].

The $\mathrm{G}$ protein family that has been studied in most detail with respect to the regulation of tuberin activity is $\mathrm{G}_{\mathrm{i}}$. To reveal the involvement of $\mathrm{G}_{\mathrm{i} / \mathrm{o}}$ proteins in a particular signaling pathway, pertussis toxin (PTX) is an indispensable tool since the toxin catalyzes the ADP-ribosylation of $G_{i / o}$ proteins and abolish their ability to become activated [78]. As mentioned in the above section, it has been demonstrated that PTX-sensitive $\mathrm{G}_{\mathrm{i}}$ family members are involved in NGF-regulated activation of Akt and phosphorylation of tuberin [29, 73]. Moreover, there have been several recent reports of GPCR-mediated activation of Akt. The majority of these responses involves PI3K and is inhibited by PTX, suggesting a requirement for $\mathrm{G}_{\mathrm{i} / \mathrm{o}}$ protein activity [79-83]. In addition, a previous study has reported that tuberin and $\mathrm{G}_{\mathrm{i}}$-coupled somatostatin type 5 receptor (SSTR5) genes form a synteny group in the Fugu genome [84]. These studies serve to illustrate the important role of $\mathrm{G}_{\mathrm{i} / \mathrm{o}}$-mediated signaling in tuberin regulation. Not surprisingly, a diverse range of $\mathrm{G}_{\mathrm{i}}$-coupled receptors are capable of regulating tuberin. For example, all three opioid receptor subtypes $(\delta, \kappa, \mu)$, $\alpha_{2}$-adrenoceptor, and muscarinic $M_{4}$ receptor are capable of inducing the phosphorylation of tuberin in both transfected and native cellular models $[29,30,73]$. Tuberin is rapidly phosphorylated in response to the $\mathrm{G}_{\mathrm{i}}$-coupled receptor agonists. Similar to the RTK-induced tuberin phosphorylation, $\mathrm{G}_{\mathrm{i}}$-coupled receptor-mediated tuberin phosphorylation is sensitive to wortmannin (a PI3K inhibitor), indicating that PI3K/Akt is the major signaling pathway involved in $\mathrm{G}_{\mathrm{i}}$-coupled receptor-induced tuberin phosphorylation. These observations are in line with the other reports which showed that $\mathrm{G}_{\mathrm{i}}$-coupled receptors are able to activate the PI3K/Akt pathway [85-87]. Moreover, like the NGF receptor, $\mathrm{G}_{\mathrm{i}}$-coupled receptors affect tuberin activity through the release of $G \beta \gamma$ complexes. The $G \beta \gamma$ complex rather than the $G \alpha_{\mathrm{i} / \mathrm{o}}$ subunit appears to serve as the major signal carrier in $\mathrm{G}_{\mathrm{i}}$-coupled receptor-induced tuberin regulation [29] (fig. 3).

Although both NGF and agonists for $\mathrm{G}_{\mathrm{i}}$-coupled receptors are able to stimulate PI3K/Akt pathway to regulate tuberin phosphorylation, the temporal profile is rather different between the two stimuli. Agonists for $\mathrm{G}_{\mathrm{i}^{-}}$ coupled receptors are only able to stimulate tuberin 
phosphorylation transiently and cannot affect the total tuberin protein level [29]. In contrast, NGF can maintain tuberin in a phosphorylated state persistently and induce tuberin degradation [29]. It was proposed that NGF may induce mTOR activity to promote survival of neuronal cells by degrading tuberin [29]. This may account for why some agonists of $\mathrm{G}_{\mathrm{i}}$-coupled receptors, such as $\kappa$ opioid and $\delta_{2}$ opioid, are only able to transiently prevent cell death [85], while most of the trophic factors can promote cell survival in a prolonged manner $[88,89]$. Although most GPCRs fail to acutely regulate total tuberin protein level, a study has demonstrated that prostaglandin (PG) $\mathrm{E}_{2}$ can down-regulate $t s c 2$ gene expression via its corresponding GPCR upon chronic stimulation of human endometrial adenocarcinoma cells [90]. In agreement with this finding, numerous studies have revealed the pro-survival ability of $\mathrm{PGE}_{2}$ [91-93].

Given the importance of tuberin in the regulation of cell survival, growth and proliferation, these observations imply that tuberin may be one of the important signaling molecules involved in GPCR-exerted effects. This is especially true for neuropeptides, which are known to regulate cell proliferation, neuronal survival, and antiapoptotic pathways $[85,94,95]$. Although survival is best predicted by coupling to $G_{i}$ pathways that regulate PI3K and Akt, other signals generated through different $G$ protein pathways are also implicated. For example, the ability of lysophosphatidic acid (LPA) and sphingosine-1phosphate (S1P) to stimulate $G_{i}, G_{q}$, and $G_{12 / 13}$ pathways allow their corresponding receptors to support cell survival and proliferation [39], which means that $\mathrm{G}_{\mathrm{q}^{-}}$or $\mathrm{G}_{12 / 13}$-coupled receptors are probably able to affect tuberin regulation (fig. 3 ).

There are several reports of $\mathrm{G}_{\mathrm{q}}$-coupled receptors stimulating Akt, PI3K, or both [96-98]. Generally, $\mathrm{G}_{\mathrm{q}}$ proteins stimulate phospholipase C (PLC) $\beta$ isoform to induce $\mathrm{Ca}^{2+}$ mobilization, which in turn regulates $\mathrm{Ca}^{2+}$ mediated effectors such as calmodulin (CaM). CaM is a well-defined mediator of a variety of intracellular signaling pathways and its activities have been shown to be contingent upon the binding of $\mathrm{Ca}^{2+}[99,100]$. A binding site for $\mathrm{CaM}$ is present in the carboxyl terminus of tuberin [101]. The importance of CaM in tuberin signaling has also been suggested in a study which demonstrated that tuberin is able to regulate the gene expression of $\mathrm{CaM}$ [102]. These findings strongly suggest that $\mathrm{G}_{\mathrm{q}}$-mediated $\mathrm{Ca}^{2+}$ signaling is able to regulate the activity of tuberin (fig. 2). There are experimental findings supporting that activated $\mathrm{G}_{\mathrm{q}}$-coupled $\alpha_{1}$-adrenergic receptor can stimulate tuberin phosphorylation to activate protein synthesis
[103]. However, activated $\mathrm{G}_{\mathrm{q}}$ proteins have also been shown to inhibit Akt kinase activity [104]. More recently, several reports have demonstrated the inhibitory ability of $\mathrm{G}_{\mathrm{q}}$-coupled receptors on Akt activity. For instance, neurotensin receptor-1, which is known to promiscuously couple to $G_{s}, G_{i}$ and $G_{q}$ [105-107], antagonizes EGFand insulin-stimulated Akt activation via $G_{q}$ signaling [108]. Likewise, luteinizing hormone-releasing hormone receptor strongly diminishes the anti-apoptotic effect of IGF-1 through inhibition of Akt activation. Our recent experimental results also demonstrated that other activated $\alpha$ subunits of the $G_{\mathrm{q}}$ family $\left(G \alpha_{11}, G \alpha_{14}\right.$, and $\left.G \alpha_{16}\right)$ can attenuate basal and EGF-induced Akt activities and the phosphorylation of tuberin in a PLC $\beta$ - and $\mathrm{Ca}^{2+}$ mobilization-independent manner [109]. In agreement, a number of recent studies have shown that the pro-apoptotic effect of $\mathrm{G}_{\mathrm{q} / 11}$ is neither dependent on PLC $\beta$ activity [110] nor on the elevation of intracellular calcium [111]. Hence, there has to be an alternative pathway for $\mathrm{G}_{\mathrm{q} / 11}$ to inhibit Akt which is independent of PLC $\beta$ and calcium signaling. One of the possible mechanisms is that $\mathrm{G} \alpha_{\mathrm{q} / 11}$ may activate protein tyrosine phosphatases which then dephosphorylate the IRS- 1 and result in the inhibition of Akt through PI3K [104, 112] (fig. 3).

The remaining question is whether other $G$ proteins, especially $G_{12 / 13}$, could affect tuberin activity. Some of our current experimental data demonstrated that activated $G_{12}$ and $G_{13}$ are able to inhibit Akt and tuberin phosphorylation via RhoA [109]. Overexpression of the constitutively active $\mathrm{G} \alpha_{12}$ and $\mathrm{G} \alpha_{13}\left(\mathrm{G} \alpha_{12} \mathrm{QL}\right.$ and $\left.\mathrm{G} \alpha_{13} \mathrm{QL}\right)$ is apparently sufficient to inhibit the EGF-induced Akt activation and tuberin phosphorylation in human embryonic kidney (HEK293) cells. Conversely, overexpression of the dominant negative mutant of RhoA blocked the $\mathrm{G} \alpha_{12} \mathrm{QL}-$ and $\mathrm{G} \alpha_{13} \mathrm{QL}-$ mediated inhibition. However, it appears that $\mathrm{G}_{12 / 13}$ is involved in other Akt regulatory pathways. Data from a separate group has observed the ability of $G \alpha_{12}$ QL to stimulate the expression as well as the activation of platelet-derived growth factor receptor $\alpha$ (PDGFR $\alpha)$ in NIH 3T3 and human astrocytoma $1321 \mathrm{~N} 1$ cells [113]. The $\mathrm{G} \alpha_{12}$-PDGFR $\alpha$ signaling axis was subsequently shown to activate the PI3-K/Akt signaling pathway via RhoA. Thus, it appears that $\mathrm{G}_{12 / 13}$ is capable of directly inhibiting EGF-induced Akt and tuberin phosphorylation, as well as stimulating Akt and tuberin phosphorylation via PDGFR $\alpha$.

In addition to the pro-survival effect, tuberin is able to regulate translation and protein synthesis via inhibition of p70 S6 kinase. Alam et al. [114] have demonstrated that the stimulation of PI3K/Akt activity by follicle-stimulat- 
ing hormone (FSH; an agonist of $\mathrm{G}_{\mathrm{s}}$-coupled receptor) culminates in the activation of signaling proteins that control mRNA translation, including mTOR, p70 S6 kinase, and the S6 ribosomal protein. They proposed that inhibition of tuberin may be involved in FSH-induced mTOR and p70 S6 kinase activations. In line with this notion, several GPCR agonists, including $\mu$-opioid, gastrin/cholecystokinin type $\mathrm{B}, \mathrm{PGF}_{2} \alpha$ and angiotensin II type I $[86,115-117]$, have also been shown to activate p70 S6 kinase in a wortmannin-sensitive manner and concomitantly stimulate Akt activity. By contrast, $\alpha$-adrenergic receptors stimulate Akt or p70 S6 kinase in a wortmannin- or LY294002 (another PI3K inhibitor)-insensitive manner [118-121], implying that, besides utilizing the PI3K pathway, some GPCRs may also regulate tuberin through other signaling pathways in order to regulate protein synthesis. Some of the identified kinases for tuberin, such as ERK and p90 RSK1, may also play a role in GPCR-induced tuberin regulation [121] (fig. 3). Further explorations on the signaling pathways of GPCR-mediated tuberin regulation may represent one of the important directions for understanding the functions of tuberin.

\section{Cooperation between RTK and GPCR}

Cross-talk between GPCRs and RTKs is an incredibly complex process, and the exact signaling molecules involved are largely dependent on the cell type and the type of receptor being activated [122]. Transactivation of RTK such as EGF receptor by GPCRs has been recognized as an important event in mitogenic and pro-survival signaling $[40,123,124]$. EGF receptor activation apparently occurs via a plasma membrane-bound metalloproteinase, which is involved in the processing of EGF-like precursor molecules that are anchored to the outer surface of the plasma membrane [125]. Recently, some reports have also demonstrated that two GPCR ligands, adenosine and PACAP, can activate Trk receptor activity to increase the survival of neural cells through stimulation of Akt activity [126-128]. However, transactivation of TrkA or EGF receptor is not necessary for the stimulation of tuberin phosphorylation by $\mathrm{G}_{\mathrm{i}}$-coupled opioid receptors and $\mathrm{M}_{4}$ mAChR $[30,129]$, indicating that different GPCRs may utilize disparate pathways to regulate their downstream effectors in order to carry out their biological functions.

While both GPCR and RTK are known to be able to affect tuberin regulation independently, what is the effect on tuberin if the two systems are simultaneously activat- ed? Our recent study showed that co-activation of $\mathrm{G}_{\mathrm{i}^{-}}$ coupled $\mathrm{M}_{4}$ muscarinic acetylcholine receptor ( $\mathrm{mAChR}$ ) and NGF receptor resulted in augmentation of Akt activity and tuberin phosphorylation in a G $\beta \gamma$ - and PI3K-dependent manner [30]. There is also evidence that suggests that activated $\mathrm{M}_{4} \mathrm{mAChR}$ is able to work together with NGF receptor to enhance cell survival. Sharing signaling components between RTKs and GPCRs may allow proximity-induced effects to generate responses more efficiently $[130,131]$. Therefore, under normal physiological conditions, agonists for GPCRs or RTKs may not work alone. Fine-tuning of cellular responses may thus be achieved by balancing the activity levels of different sets of GPCRs and RTKs on the target cells (fig. 3).

\section{Conclusion}

The identification of the phosphorylation sites of tuberin and the regulation of tuberin by RTKs a few years ago has initiated the intensive research on tuberin regulation. An increasing body of evidence has suggested that the functional activity of tuberin could be regulated by different signaling molecules and kinases, including PI3K, Akt, ERK, 14-3-3 proteins, and G proteins. Current data supports a model that, apart from RTKs, GPCRs are also able to regulate tuberin activity. Direct evidence has shown that $\mathrm{G}_{\mathrm{i} / \mathrm{o}^{-}}$and $\mathrm{G}_{\mathrm{q}^{-}}$-coupled receptors can regulate tuberin phosphorylation in a PI3K-dependent or -independent manner (fig. 3), while $\mathrm{G}_{12 / 13}$ may have a dual role in regulating tuberin. The role of these $G$ proteins in the regulation of tuberin activity should be explored in detail. Furthermore, the differential temporal profiles between RTK- and GPCR-regulated tuberin phosphorylation is also an interesting area to be investigated in the future. In the advent of new technological developments, the study of protein phosphorylation becomes increasingly accurate and rapid. In 2004 a group developed a protocol utilizing stable isotope-based quantitative mass spectrometry (MS) [132]. This protocol was able to simultaneously detect and quantify temporal changes in all of a protein's phosphorylation sites. Comparisons with traditional biochemical methods such as immunoblotting and activity assays validated the reliability of the MSbased method. These tools become increasingly important as we try to elucidate protein phosphorylation biochemical pathways. Tuberin is not only regulated by RTKs and GPCRs. A recent study has demonstrated that the forkhead transcription factor FoxO is capable of binding to tuberin [133]. FoxO binds to an adjacent region 
near the GAP domain, thus inhibiting the GAP activity towards Rheb. With the diverse array of tuberin regulators, future studies on the tuberin pathways will not only be interesting, but also challenging.

\section{Acknowledgements}

This work was supported in part by grants from the Research Grants Council of Hong Kong (HKUST 3/03C), the University Grants Committee (AoE/B-15/01), and the Hong Kong Jockey Club.

\section{References}

1 Smith M: Mapping of the tuberous sclerosis genes. Int J Neurol 1991;25-26:81-88.

-2 Van Slegtenhorst M, de Hoogt R, Hermans C, Nellist M, Janssen B, Verhoef S, Lindhout D, van den Ouweland A, Halley D, Young J, Burley M, Jeremiah S, Woodward K, Nahmias J, Fox M, Ekong R, Osborne J, Wolfe J, Povey S, Snell RG, Cheadle JP, Jones AC, Tachataki M, Ravine D, Sampson JR, Reeve MP, Richardson P, Wilmer F, Munro C, Hawkins TL, Sepp T, Ali JB, Ward S, Green AJ, Yates JR, Kwiatkowska J, Henske EP, Short MP, Haines JH, Jozwiak S, Kwiatkowski DJ: Identification of the tuberous sclerosis gene Tsc1 on chromosome 9q34. Science 1997;277: 805-808.

3 Young J, Povey S: The genetic basis of tuberous sclerosis. Mol Med Today 1998;4:313319.

4 Cheadle JP, Reeve MP, Sampson JR, Kwiatkowski DJ: Molecular genetic advances in tuberous sclerosis. Hum Genet 2000;107:97114.

-5 Nellist M, van Slegtenhorst MA, Goedbloed $M$, van den Ouweland AM, Halley DJ, van der Sluijs P: Characterization of the cytosolic tuberin-hamartin complex. Tuberin is a cytosolic chaperone for hamartin. J Biol Chem 1999;274:35647-35652.

-6 Yamamoto Y, Jones KA, Mak BC, Muehlenbachs A, Yeung RS: Multicompartmental distribution of the tuberous sclerosis gene products, hamartin and tuberin. Arch Biochem Biophys 2002;404:210-217.

$\checkmark 7$ Dan HC, Sun M, Yang L, Feldman RI, Sui XM, Ou CC, Nellist M, Yeung RS, Halley DJ, Nicosia SV, Pledger WJ, Cheng JQ: Phosphatidylinositol 3-kinase/Akt pathway regulates tuberous sclerosis tumor suppressor complex by phosphorylation of tuberin. J Biol Chem 2002;277:35364-35370.

-8 Liu H, Radisky DC, Nelson CM, Zhang H, Fata JE, Roth RA, Bissell MJ: Mechanism of Aktl inhibition of breast cancer cell invasion reveals a protumorigenic role for TSC2. Proc Natl Acad Sci USA 2006;103:4134-4139.

-9 Manning BD, Tee AR, Logsdon MN, Blenis J, Cantley LC: Identification of the tuberous sclerosis complex-2 tumor suppressor gene product tuberin as a target of the phosphoinositide 3-kinase/Akt pathway. Mol Cell 2002;10:151-162.

10 Rosner M, Freilinger A, Hengstschlager M: Akt regulates nuclear/cytoplasmic localization of tuberin. Oncogene 2007;26:521-531.
11 Soucek T, Pusch O, Wienecke R, DeClue JE, Hengstschlager M: Role of the tuberous sclerosis gene- 2 product in cell cycle control. Loss of the tuberous sclerosis gene-2 induces quiescent cells to enter S phase. J Biol Chem 1997;272:29301-29308.

-12 Miloloza A, Rosner M, Nellist M, Halley D, Bernaschek G, Hengstschlager M: The Tscl gene product, hamartin, negatively regulates cell proliferation. Hum Mol Genet 2000;9: 1721-1727.

13 Clements D, Mayer RJ, Johnson SR: Subcellular distribution of the Tsc2 gene product tuberin in human airway smooth muscle cells is driven by multiple localization sequences and is cell-cycle dependent. Am J Physiol 2007;292:L258-L266.

-14 Cai SL, Tee AR, Short JD, Bergeron JM, Kim J, Shen J, Guo R, Johnson CL, Kiguchi K, Walker CL: Activity of TSC2 is inhibited by Akt-mediated phosphorylation and membrane partitioning. J Cell Biol 2006;173:279289.

15 Maheshwar MM, Sandford R, Nellist M, Cheadle JP, Sgotto B, Vaudin M, Sampson JR: Comparative analysis and genomic structure of the tuberous sclerosis 2 (Tsc2) gene in human and pufferfish. Hum Mol Genet 1996;5:562.

16 Olsson PG, Schofield JN, Edwards YH, Frischauf AM: Expression and differential splicing of the mouse Tsc2 homolog. Mamm Genome 1996;7:212-215.

17 Matsumoto S, Bandyopadhyay A, Kwiatkowski DJ, Maitra U, Matsumoto T: Role of the Tsc1-Tsc2 complex in signaling and transport across the cell membrane in the fission yeast Schizosaccharomyces pombe. Genetics 2002;161:1053-1063.

18 Ito N, Rubin GM: Gigas, a Drosophila homo$\log$ of tuberous sclerosis gene product-2, regulates the cell cycle. Cell 1999;96:529-539.

19 Yeung RS, Xiao GH, Jin F, Lee WC, Testa JR, Knudson AG: Predisposition to renal carcinoma in the Eker rat is determined by germline mutation of the tuberous sclerosis 2 (TSC2) gene. Proc Natl Acad Sci USA 1994; 91:11413-11416.

20 Kobayashi T, Urakami S, Cheadle JP, Aspinwall R, Harris P, Sampson JR, Hino O: Identification of a leader exon and a core promoter for the rat tuberous sclerosis 2 (Tsc2) gene and structural comparison with the human homolog. Mamm Genome 1997;8:554-558.
21 Crino PB, Henske EP: New developments in the neurobiology of the tuberous sclerosis complex. Neurology 1999;53:1384-1390.

22 Hino O, Majima S, Kobayashi T, Honda S, Momose S, Kikuchi Y, Mitani H: Multistep renal carcinogenesis as gene expression disease in tumor suppressor Tsc2 gene mutant model - genotype, phenotype and environment. Mutat Res 2001;477:155-164.

23 Roach ES, Gomez MR, Northrup H: Tuberous sclerosis complex consensus conference: revised clinical diagnostic criteria. J Child Neurol 1998;13:624-628.

24 Halley DJ: Tuberous sclerosis: between genetic and physical analysis. Acta Genet Med Gemellol (Roma) 1996;45:63-75.

25 Onda H, Lueck A, Marks PW, Warren HB, Kwiatkowski DJ: Tsc2 ${ }^{+/-}$mice develop tumors in multiple sites that express gelsolin and are influenced by genetic background. J Clin Invest 1999;104:687-695.

26 Kwiatkowski DJ: Tuberous sclerosis: from tubers to mTOR. Ann Hum Genet 2003;67: 87-96.

27 Schmelzle T, Hall MN: TOR, a central controller of cell growth. Cell 2000;103:253262.

28 Shamji AF, Nghiem P, Schreiber SL: Integration of growth factor and nutrient signaling: implications for cancer biology. Mol Cell 2003;12:271-280

29 Wu EH, Wong YH: Involvement of $\mathrm{G}_{\mathrm{i} / \mathrm{o}}$ proteins in nerve growth factor-stimulated phosphorylation and degradation of tuberin in PC-12 cells and cortical neurons. Mol Pharmacol 2005;67:1195-1205.

$30 \mathrm{Wu}$ EH, Wong YH: Activation of muscarinic $\mathrm{M}_{4}$ receptor augments NGF-induced prosurvival Akt signaling in PC12 cells. Cell Signal 2006;18:285-293.

-31 Inoki K, Zhu T, Guan KL: Tsc2 mediates cellular energy response to control cell growth and survival. Cell 2003;115:577-590.

32 Li S, Braverman R, Li H, Vass WC, Lowy DR, DeClue JE: Regulation of cell morphology and adhesion by the tuberous sclerosis complex $(\mathrm{Tsc} 1 / 2)$ gene products in human kidney epithelial cells through increased E-cadherin/-catenin activity. Mol Carcinog 2003; 37:98-109.

33 Astrinidis A, Cash TP, Hunter DS, Walker CL, Chernoff J, Henske EP: Tuberin, the tuberous sclerosis complex 2 tumor suppressor gene product, regulates Rho activation, cell adhesion and migration. Oncogene 2002;21: 8470-8476. 
-34 Tavazoie SF, Alvarez VA, Ridenour DA, Kwiatkowski DJ, Sabatini BL: Regulation of neuronal morphology and function by the tumor suppressors TSC1 and TSC2. Nat Neurosci 2005;8:1727-1734.

-35 Jones KA, Jiang X, Yamamoto Y, Yeung RS: Tuberin is a component of lipid rafts and mediates caveolin-1 localization: role of TSC2 in post-Golgi transport. Exp Cell Res 2004; 295:512-524.

\36 Nellist M, Goedbloed MA, de Winter C, Verhaaf B, Jankie A, Reuser AJ, van den Ouweland AM, van der Sluijs P, Halley DJ: Identification and characterization of the interaction between tuberin and 14-3-3 $\zeta$. J Biol Chem 2002;277:39417-39424.

-37 Inoki K, Li Y, Zhu T, Wu J, Guan KL: Tsc2 is phosphorylated and inhibited by Akt and suppresses mTOR signalling. Nat Cell Biol 2002;4:648-657.

-38 Razani B, Woodman SE, Lisanti MP: Caveolae: from cell biology to animal physiology. Pharmacol Rev 2002;54:431-467.

>39 Radeff-Huang J, Seasholtz TM, Matteo RG, Brown JH: G protein-mediated signaling pathways in lysophospholipid induced cell proliferation and survival. J Cell Biochem 2004;92:949-966.

-40 Tegeder I, Geisslinger G: Opioids as modulators of cell death and survival - unraveling mechanisms and revealing new indications. Pharmacol Rev 2004;56:351-369.

41 Franke TF, Kaplan DR, Cantley LC: PI3K: Downstream AKTion blocks apoptosis. Cell 1997;88:435-437.

-42 Wymann MP, Pirola L: Structure and function of phosphoinositide 3-kinases. Biochim Biophys Acta 1998;1436:127-150.

$\checkmark 4$ Plas DR, Thompson CB: Akt activation promotes degradation of tuberin and $\mathrm{FOXO} 3 \mathrm{a}$ via the proteasome. J Biol Chem 2003;278: 12361-12366.

$\checkmark 4$ Gao X, Zhang Y, Arrazola P, Hino O, Kobayashi T, Yeung RS, Ru B, Pan D: TSC tumour suppressor proteins antagonize amino-acid-TOR signalling. Nat Cell Biol 2002; 4:699-704.

-45 Potter CJ, Pedraza LG, Xu T: Akt regulates growth by directly phosphorylating TSC2. Nat Cell Biol 2002;4:658-665.

46 Li Y, Inoki K, Vacratsis P, Guan KL: The p38 and MK2 kinase cascade phosphorylates tuberin, the tuberous sclerosis 2 gene product, and enhances its interaction with 14-3-3. J Biol Chem 2003;278:13663-13671.

-47 Roux PP, Ballif BA, Anjum R, Gygi SP, Blenis $\mathrm{J}$ : Tumor-promoting phorbol esters and activated ras inactivate the tuberous sclerosis tumor suppressor complex via p90 ribosomal S6 kinase. Proc Natl Acad Sci USA 2004;101: 13489-13494.

48 Astrinidis A, Henske EP: Tuberous sclerosis complex: linking growth and energy signaling pathways with human disease. Oncogene 2005;24:7475-7481.
49 Ma L, Chen Z, Erdjument-Bromage H, Tempst P, Pandolfi PP: Phosphorylation and functional inactivation of TSC2 by ERK implications for tuberous sclerosis and cancer pathogenesis. Cell 2005;121:179-193.

50 Yaffe MB, Cantley LC: Signal transduction. Grabbing phosphoproteins. Nature 1999; 402:30-31.

51 Nellist M, Goedbloed MA, Halley DJ: Regulation of tuberous sclerosis complex (TSC) function by 14-3-3 proteins. Biochem Soc Trans 2003;31:587-591.

52 Shumway SD, Li Y, Xiong Y: 14-3-3 binds to and negatively regulates the tuberous sclerosis complex 2 (TSC2) tumor suppressor gene product, tuberin. J Biol Chem 2003;278: 2089-2092.

53 Yoon HS, Monks TJ, Everitt JI, Walker CL, Lau SS: Cell proliferation is insufficient, but loss of tuberin is necessary, for chemically induced nephrocarcinogenicity. Am J Physiol Renal Physiol 2002;283:F262-F270.

54 Finlay GA, York B, Karas RH, Fanburg BL, Zhang H, Kwiatkowski DJ, Noonan DJ: Estrogen-induced smooth muscle cell growth is regulated by tuberin and associated with altered activation of platelet-derived growth factor receptor- $\beta$ and ERK-1/2. J Biol Chem 2004;279:23114-23122.

55 Yoon HS, Ramachandiran S, Chacko MA, Monks TJ, Lau SS: Tuberous sclerosis-2 tumor suppressor modulates ERK and B-Raf activity in transformed renal epithelial cells. Am J Physiol Renal Physiol 2004;286:F417F424.

56 Potter CJ, Huang H, Xu T: Drosophila TSC1 functions with TSC2 to antagonize insulin signaling in regulating cell growth, cell proliferation, and organ size. Cell 2001;105:357368.

57 Gao X, Pan D: TSC1 and TSC2 tumor suppressors antagonize insulin signaling in cell growth. Genes Dev 2001;15:1383-1392.

58 Manning BD: Balancing Akt with S6K: Implications for both metabolic diseases and tumorigenesis. J Cell Biol 2004;167:399_ 403.

59 Shah OJ, Wang Z, Hunter T: Inappropriate activation of the TSC/Rheb/mTOR/S6K cassette induces IRS1/2 depletion, insulin resistance, and cell survival deficiencies. Curr Biol 2004;14:1650-1656.

60 Radimerski T, Montagne J, HemmingsMieszczak M, Thomas G: Lethality of drosophila lacking TSC tumor suppressor function rescued by reducing dS6K signaling. Genes Dev 2002;16:2627-2632.

61 Harrington LS, Findlay GM, Gray A, Tolkacheva T, Wigfield S, Rebholz H, Barnett J, Leslie NR, Cheng S, Shepherd PR, Gout I, Downes CP, Lamb RF: The TSC1-2 tumor suppressor controls insulin-PI3K signaling via regulation of IRS proteins. J Cell Biol 2004; 166:213-223.
62 Zhang H, Cicchetti G, Onda H, Koon HB, Asrican K, Bajraszewski N, Vazquez F, Carpenter CL, Kwiatkowski DJ: Loss of TSC1/ TSC2 activates mTOR and disrupts PI3KAkt signaling through downregulation of PDGFR. J Clin Invest 2003;112:1223-1233.

-63 Onda H, Crino PB, Zhang H, Murphey RD, Rastelli L, Gould Rothberg BE, Kwiatkowski DJ: Tsc2 null murine neuroepithelial cells are a model for human tuber giant cells, and show activation of an mTOR pathway. Mol Cell Neurosci 2002;21:561-574.

64 Jaeschke A, Hartkamp J, Saitoh M, Roworth W, Nobukuni T, Hodges A, Sampson J, Thomas G, Lamb R: Tuberous sclerosis complex tumor suppressor-mediated S6 kinase inhibition by phosphatidylinositide-3-OH kinase is mTOR independent. J Cell Biol 2002;159:217-224.

65 Wiatkowski DJ, Zhang H, Bandura JL, Heiberger KM, Glogauer M, el-Hashemite N, Onda H: A mouse model of TSC1 reveals sexdependent lethality from liver hemangiomas, and up-regulation of p70S6 kinase activity in Tsc1 null cells. Hum Mol Genet 2002;11:525-534.

66 Miranda C, Greco A, Miele C, Pierotti MA, Van Obberghen E: IRS-1 and IRS-2 are recruited by TrkA receptor and oncogenic TrkT1. J Cell Physiol 2001;186:35-46.

67 Rakhit S, Pyne S, Pyne NJ: Nerve growth factor stimulation of $\mathrm{p} 42 / \mathrm{p} 44$ mitogen-activated protein kinase in pc12 cells: role of $\mathrm{G}_{\mathrm{i} / \mathrm{o}} \mathrm{G}$ protein-coupled receptor kinase $2, \beta$-arrestin 1, and endocytic processing. Mol Pharmacol 2001;60:63-70.

68 Rothenberg PL, Kahn CR: Insulin inhibits pertussis toxin-catalyzed ADP-ribosylation of G-proteins. Evidence for a novel interaction between insulin receptors and G-proteins. J Biol Chem 1988;263:15546-15552.

-69 Luttrell L, Kilgour E, Larner J, Romero G: A pertussis toxin-sensitive G-protein mediates some aspects of insulin action in $\mathrm{BC} 3 \mathrm{H}-1$ murine myocytes. J Biol Chem 1990;265: 16873-16879.

70 Liang MN, Garrison JC: The epidermal growth factor receptor is coupled to a pertussis toxin-sensitive guanine nucleotide regulatory protein in rat hepatocytes. J Biol Chem 1991;266:13342-13349.

71 Nishimoto I: The IGF-II receptor system: A $\mathrm{G}$ protein-linked mechanism. Mol Reprod Dev 1993;35:398-407.

72 Hallak H, Seiler AE, Green JS, Ross BN, Rubin R: Association of heterotrimeric $G_{i}$ with the insulin-like growth factor-I receptor. Release of GGG subunits upon receptor activation. J Biol Chem 2000;275:2255-2258.

$73 \mathrm{Wu}$ EH, Wong YH: Pertussis toxin-sensitive $\mathrm{G}_{\mathrm{i} / \mathrm{o}}$ proteins are involved in nerve growth factor-induced pro-survival Akt signaling cascade in PC12 cells. Cell Signal 2005;17: 881-890. 
74 Galisteo ML, Dikic I, Batzer AG, Langdon WY, Schlessinger J: Tyrosine phosphorylation of the $\mathrm{c}$-cbl proto-oncogene protein product and association with epidermal growth factor (EGF) receptor upon EGF stimulation. J Biol Chem 1995;270:2024220245.

75 Wu C, Lai CF, Mobley WC: Nerve growth factor activates persistent Rap1 signaling in endosomes. J Neurosci 2001;21:5406-5416.

76 Momose H, Kurosu H, Tsujimoto N, Kontani K, Tsujita K, Nishina H, Katada T: Dual phosphorylation of phosphoinositide 3-kinase adaptor Grb2-associated binder 2 is responsible for superoxide formation synergistically stimulated by Fc $\gamma$ and formylmethionyl-leucyl-phenylalanine receptors in differentiated THP-1 cells. J Immunol 2003;171:4227-4234.

77 Morris AJ, Malbon CC: Physiological regulation of $G$ protein-linked signaling. Physiol Rev 1999;79:1373-1430.

78 Hepler JR, Gilman AG: G proteins. Trends Biochem Sci 1992;17:383-387.

$>79$ Murga C, Laguinge L, Wetzker R, Cuadrado A, Gutkind JS: Activation of Akt/protein kinase $B$ by $G$ protein-coupled receptors. A role for $\alpha$ and $\beta \gamma$ subunits of heterotrimeric G proteins acting through phosphatidylinositol-3-OH kinase. J Biol Chem 1998;273: 19080-19085.

-80 Gomez del Pulgar T, Velasco G, Guzman M: The CB1 cannabinoid receptor is coupled to the activation of protein kinase B/Akt. Biochem J 2000;347:369-373.

81 Hu X, Haney N, Kropp D, Kabore AF, Johnston JB, Gibson SB: Lysophosphatidic acid (LPA) protects primary chronic lymphocytic leukemia cells from apoptosis through LPA receptor activation of the anti-apoptotic protein Akt/PKB. J Biol Chem 2005;280:94989508.

-82 Tilton B, Andjelkovic M, Didichenko SA, Hemmings BA, Thelen M: G protein-coupled receptors and $\mathrm{Fc} \gamma$ receptors mediate activation of Akt/protein kinase B in human phagocytes. J Biol Chem 1997;272:2809628101.

83 Morales-Ruiz M, Lee MJ, Zollner S, Gratton JP, Scotland R, Shiojima I, Walsh K, Hla T, Sessa WC: Sphingosine 1-phosphate activates Akt, nitric oxide production, and chemotaxis through a $\mathrm{G}_{\mathrm{i}}$ protein/phosphoinositide 3-kinase pathway in endothelial cells. J Biol Chem 2001;276:19672-19677.

84 Sandford R, Sgotto B, Burn T, Brenner S: The tuberin (Tsc2), autosomal dominant polycystic kidney disease (PKD1), and somatostatin type $\mathrm{V}$ receptor (SSTR5) genes form a synteny group in the Fugu genome. Genomics 1996;38:84-86.

85 Dermitzaki E, Chatzaki E, Gravanis A, Margioris AN: Opioids transiently prevent activation of apoptotic mechanisms following short periods of serum withdrawal. J Neurochem 2000;74:960-969.
86 Polakiewicz RD, Schieferl SM, Gingras AC, Sonenberg N, Comb MJ: Mu-opioid receptor activates signaling pathways implicated in cell survival and translational control. J Biol Chem 1998;273:23534-23541.

87 Iglesias M, Segura MF, Comella JX, Olmos $\mathrm{G}$ : $\mathrm{Mu}$-opioid receptor activation prevents apoptosis following serum withdrawal in differentiated SH-SY5Y cells and cortical neurons via phosphatidylinositol 3-kinase. Neuropharmacology 2003;44:482-492.

88 Virdee K, Xue L, Hemmings BA, Goemans C, Heumann R, Tolkovsky AM: Nerve growth factor-induced $\mathrm{PKB} / \mathrm{Akt}$ activity is sustained by phosphoinositide 3-kinase dependent and independent signals in sympathetic neurons. Brain Res 1999;837:127142.

89 Orike N, Middleton G, Borthwick E, Buchman V, Cowen T, Davies AM: Role of PI 3kinase, Akt and Bcl-2-related proteins in sustaining the survival of neurotrophic factor-independent adult sympathetic neurons. J Cell Biol 2001;154:995-1005.

90 Sales KJ, Battersby S, Williams AR, Anderson RA, Jabbour HN: Prostaglandin $\mathrm{E}_{2}$ mediates phosphorylation and down-regulation of the tuberous sclerosis-2 tumor suppressor (tuberin) in human endometrial adenocarcinoma cells via the Akt signaling pathway. J Clin Endocrinol Metab 2004;89: 6112-6118.

91 Aoudjit L, Potapov A, Takano T: Prostaglandin $E_{2}$ promotes cell survival of glomerular epithelial cells via the EP4 receptor. Am J Physiol Renal Physiol 2006;290:F1534F1542.

92 Echeverria V, Clerman A, Dore S: Stimulation of PGE receptors EP2 and EP4 protects cultured neurons against oxidative stress and cell death following $\beta$-amyloid exposure. Eur J Neurosci 2005;22:2199-2206.

93 Tessner TG, Muhale F, Riehl TE, Anant S, Stenson WF: Prostaglandin $\mathrm{E}_{2}$ reduces radiation-induced epithelial apoptosis through a mechanism involving Akt activation and Bax translocation. J Clin Invest 2004;114: 1676-1685.

94 Dhanasekaran N, Tsim ST, Dermott JM, Onesime D: Regulation of cell proliferation by G proteins. Oncogene 1998;17:1383-1394.

95 Hayashi T, Tsao LI, Su TP: Antiapoptotic and cytotoxic properties of $\delta$ opioid peptide [Dala $^{2}, \mathrm{D}-\mathrm{leu}{ }^{5}$ ]enkephalin in PC12 cells. Synapse 2002;43:86-94.

96 Tang X, Batty IH, Downes CP: Muscarinic receptors mediate phospholipase $\mathrm{C}$-dependent activation of protein kinase $\mathrm{B}$ via $\mathrm{Ca}^{2+}$, ErbB3, and phosphoinositide 3-kinase in $1321 \mathrm{~N} 1$ astrocytoma cells. J Biol Chem 2002; 277:338-344.

97 Liebmann C, Bohmer FD: Signal transduction pathways of $G$ protein-coupled receptors and their cross-talk with receptor tyrosine kinases: lessons from bradykinin signaling. Curr Med Chem 2000;7:911-943.
98 Eguchi S, Iwasaki H, Ueno H, Frank GD, Motley ED, Eguchi K, Marumo F, Hirata Y, Inagami T: Intracellular signaling of angiotensin II-induced p70 S6 kinase phosphorylation at $\mathrm{Ser}^{411}$ in vascular smooth muscle cells. Possible requirement of epidermal growth factor receptor, Ras, extracellular signal-regulated kinase, and Akt. J Biol Chem 1999;274:36843-36851.

99 Van Eldik LJ, Zendegui JG, Marshak DR, Watterson DM: Calcium-binding proteins and the molecular basis of calcium action. Int Rev Cytol 1982;77:1-61.

100 Means AR: Regulatory cascades involving calmodulin-dependent protein kinases. Mol Endocrinol 2000;14:4-13.

101 Noonan DJ, Lou D, Griffith N, Vanaman TC: A calmodulin binding site in the tuberous sclerosis 2 gene product is essential for regulation of transcription events and is altered by mutations linked to tuberous sclerosis and lymphangioleiomyomatosis. Arch Biochem Biophys 2002;398:132-140.

102 Orimoto K, Tsuchiya H, Sakurai J, Nishizawa $\mathrm{M}$, Hino O: Identification of CDNAs induced by the tumor suppressor TSC2 gene using a conditional expression system in TSC2 mutant (Eker) rat renal carcinoma cells. Biochem Biophys Res Commun 1998; 247:728-733.

103 Rolfe M, McLeod LE, Pratt PF, Proud CG: Activation of protein synthesis in cardiomyocytes by the hypertrophic agent phenylephrine requires the activation of ERK and involves phosphorylation of tuberous sclerosis complex 2 (TSC2). Biochem J 2005;388:973-984.

104 Bommakanti RK, Vinayak S, Simonds WF: Dual regulation of Akt/protein kinase B by heterotrimeric $\mathrm{G}$ protein subunits. J Biol Chem 2000;275:38870-38876.

105 Ehlers RA, Zhang Y, Hellmich MR, Evers BM: Neurotensin-mediated activation of MAPK pathways and AP-1 binding in the human pancreatic cancer cell line, MIA PaCa-2. Biochem Biophys Res Commun 2000;269:704-708.

106 Gailly P, Najimi M, Hermans E: Evidence for the dual coupling of the rat neurotensin receptor with pertussis toxin-sensitive and insensitive G-proteins. FEBS Lett 2000; 483:109-113.

107 Najimi M, Gailly P, Maloteaux JM, Hermans E: Distinct regions of C-terminus of the high affinity neurotensin receptor mediate the functional coupling with pertussis toxin sensitive and insensitive G-proteins. FEBS Lett 2002;512:329-333.

108 Liu F, Yang P, Baez M, Ni B: Neurotensin negatively modulates Akt activity in neurotensin receptor-1-transfected AV12 cells. J Cell Biochem 2004;92:603-611.

109 Wu EH, Tam BH, Wong YH: Constitutively active $\alpha$ subunits of $\mathrm{G}_{\mathrm{q} / 11}$ and $\mathrm{G}_{12 / 13}$ families inhibit activation of the pro-survival Akt signaling cascade. FEBS J 2006;273:23882398. 
-110 Ueda H, Morishita R, Itoh H, Narumiya S, Mikoshiba K, Kato K, Asano T: $\mathrm{G}_{11}$ induces caspase-mediated proteolytic activation of Rho-associated kinase, ROCK-I, in HeLa cells. J Biol Chem 2001;276:42527-42533.

- 111 Ueda H, Morishita R, Narumiya S, Kato K, Asano $\mathrm{T}$ : $\mathrm{G} \alpha_{\mathrm{q} / 11}$ signaling induces apoptosis through two pathways involving reduction of Akt phosphorylation and activation of RhoA in HeLa cells. Exp Cell Res 2004;298: 207-217.

112 Baudhuin LM, Cristina KL, Lu J, Xu Y: Akt activation induced by lysophosphatidic acid and sphingosine-1-phosphate requires both mitogen-activated protein kinase kinase and p38 mitogen-activated protein kinase and is cell-line specific. Mol Pharmacol 2002;62:660-671.

- 113 Kumar RN, Ha JH, Radhakrishnan R, Dhanasekaran DN: Transactivation of plateletderived growth factor receptor $\alpha$ by the GTPase-deficient activated mutant of $\mathrm{GG}_{12}$. Mol Cell Biol 2006;26:50-62.

-114 Alam H, Maizels ET, Park Y, Ghaey S, Feiger ZJ, Chandel NS, Hunzicker-Dunn M: Follicle-stimulating hormone activation of hypoxia-inducible factor-1 by the phosphatidylinositol 3-kinase/Akt/Ras homolog enriched in brain (Rheb)/mammalian target of rapamycin (mTOR) pathway is necessary for induction of select protein markers of follicular differentiation. J Biol Chem 2004;279:19431-19440.

- 115 Desbois C, Huerou-Luron IL, Dufresne M, Estival A, Clerc P, Rome V, Clemente F, Guilloteau P, Fourmy D: The CCKB/gastrin receptor is coupled to the regulation of enzyme secretion, protein synthesis and p70 S6 kinase activity in acinar cells from ElasCCKB transgenic mice. Eur J Biochem 1999;266:1003-1010.

- 116 Rao GN, Madamanchi NR, Lele M, Gadiparthi L, Gingras AC, Eling TE, Sonenberg $\mathrm{N}$ : A potential role for extracellular signalregulated kinases in prostaglandin $\mathrm{F}_{2} \alpha$-induced protein synthesis in smooth muscle cells. J Biol Chem 1999;274:12925-12932.

- 117 Graves LM, He Y, Lambert J, Hunter D, Li $\mathrm{X}$, Earp HS: An intracellular calcium signal activates $\mathrm{p} 70$ but not $\mathrm{p} 90$ ribosomal $\mathrm{S} 6 \mathrm{ki}$ nase in liver epithelial cells. J Biol Chem 1997;272:1920-1928.
118 Moule SK, Welsh GI, Edgell NJ, Foulstone EJ, Proud CG, Denton RM: Regulation of protein kinase $B$ and glycogen synthase kinase- 3 by insulin and $\beta$-adrenergic agonists in rat epididymal fat cells. Activation of protein kinase B by wortmannin-sensitive and -insensitive mechanisms. J Biol Chem 1997;272:7713-7719.

119 Wang L, Gout I, Proud CG: Cross-talk between the Erk and p70 S6 kinase (S6K) signaling pathways. MEK-dependent activation of S6K2 in cardiomyocytes. J Biol Chem 2001;276:32670-32677.

120 Ballou LM, Cross ME, Huang S, McReynolds EM, Zhang BX, Lin RZ: Differential regulation of the phosphatidylinositol 3-kinase/Akt and p70 S6 kinase pathways by the $\alpha_{1 \mathrm{~A}}$-adrenergic receptor in Rat-1 fibroblasts. J Biol Chem 2000;275:4803-4809.

121 Wang L, Proud CG: Ras/Erk signaling is essential for activation of protein synthesis by $\mathrm{G}_{\mathrm{a}}$ protein-coupled receptor agonists in adult cardiomyocytes. Circ Res 2002;91: 821-829.

122 Lowes VL, Ip NY, Wong YH: Integration of signals from receptor tyrosine kinases and $\mathrm{G}$ protein-coupled receptors. Neurosignals 2002;11:5-19.

123 Nair VD, Sealfon SC: Agonist-specific transactivation of phosphoinositide 3-kinase signaling pathway mediated by the dopamine D2 receptor. J Biol Chem 2003;278: 47053-47061.

124 Daub H, Weiss FU, Wallasch C, Ullrich A: Role of transactivation of the EGF receptor in signalling by G-protein-coupled receptors. Nature 1996;379:557-560.

125 Belcheva MM, Szucs M, Wang D, Sadee W, Coscia CJ: Mu-opioid receptor-mediated ERK activation involves calmodulin-dependent epidermal growth factor receptor transactivation. J Biol Chem 2001;276: 33847-33853.

126 Lee FS, Rajagopal R, Chao MV: Distinctive features of Trk neurotrophin receptor transactivation by $\mathrm{G}$ protein-coupled receptors. Cytokine Growth Factor Rev 2002; 13:11-17.
127 Lee FS, Rajagopal R, Kim AH, Chang PC, Chao MV: Activation of Trk neurotrophin receptor signaling by pituitary adenylate cyclase-activating polypeptides. J Biol Chem 2002;277:9096-9102.

128 Rajagopal R, Chen ZY, Lee FS, Chao MV: Transactivation of Trk neurotrophin receptors by G-protein-coupled receptor ligands occurs on intracellular membranes. J Neurosci 2004;24:6650-6658.

$129 \mathrm{Wu}$ EH, Wong YH: Activation of $\delta$-, $\mathrm{\kappa}-$, and $\mu$-opioid receptors induces phosphorylation of tuberin in transfected HEK 293 cells and native cells. Biochem Biophys Res Commun 2005;334:838-844.

- 130 Alderton F, Rakhit S, Kong KC, Palmer T, Sambi B, Pyne S, Pyne NJ: Tethering of the platelet-derived growth factor $\beta$ receptor to G-protein-coupled receptors. A novel platform for integrative signaling by these receptor classes in mammalian cells. J Biol Chem 2001;276:28578-28585.

131 Waters CM, Connell MC, Pyne S, Pyne NJ: $\mathrm{c}$-Src is involved in regulating signal transmission from PDGFP receptor-GPCRs complexes in mammalian cells. Cell Signal 2005;17:263-277.

-132 Ballif BA, Roux PP, Gerber SA, MacKeigan JP, Blenis J, Gygi SP: Quantitative phosphorylation profiling of the Erk/p90 ribosomal S6 kinase-signaling cassette and its targets, the tuberous sclerosis tumor suppressors. Proc Natl Acad Sci USA 2005;102: 667-672.

133 Cao Y, Kamioka Y, Yokoi N, Kobayashi T, Hino O, Onodera M, Mochizuki N, Nakae $\mathrm{J}$ : Interaction of FOXO1 and TSC2 induces insulin resistance through activation of the mammalian target of rapamycin/p70 S6K pathway. J Biol Chem 2006;281:4024240251.

134 Hodges AK, Li S, Maynard J, Parry L, Braverman R, Cheadle JP, DeClue JE, Sampson JR: Pathological mutations in Tscl and Tsc2 disrupt the interaction between hamartin and tuberin. Hum Mol Genet 2001;10:2899-2905.

135 Li Y, Inoki K, Guan KL: Biochemical and functional characterizations of small GTPase Rheb and TSC2 GAP activity. Mol Cell Biol 2004;24:7965-7975. 